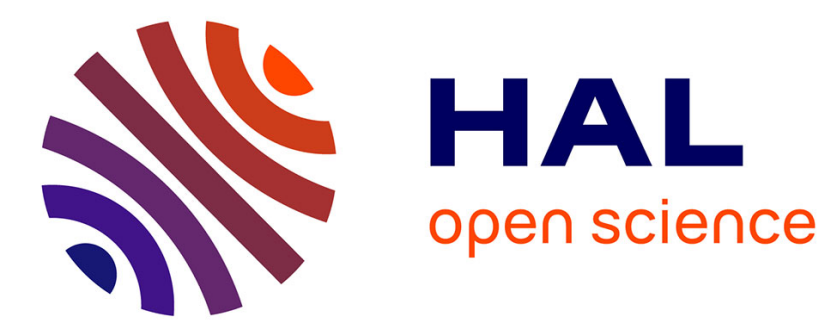

\title{
Ecological economics and scientific controversies. Lessons from some recent policy making in the EEC
} Jean-Charles Hourcade, Jean-Michel A Salles, Daniel Théry

\section{To cite this version:}

Jean-Charles Hourcade, Jean-Michel A Salles, Daniel Théry. Ecological economics and scientific controversies. Lessons from some recent policy making in the EEC. Ecological Economics, 1992, 6 (3), pp.211-233. 10.1016/0921-8009(92)90026-O . hal-02961810

\section{HAL Id: hal-02961810 \\ https://hal.science/hal-02961810}

Submitted on 13 Oct 2020

HAL is a multi-disciplinary open access archive for the deposit and dissemination of scientific research documents, whether they are published or not. The documents may come from teaching and research institutions in France or abroad, or from public or private research centers.
L'archive ouverte pluridisciplinaire HAL, est destinée au dépôt et à la diffusion de documents scientifiques de niveau recherche, publiés ou non, émanant des établissements d'enseignement et de recherche français ou étrangers, des laboratoires publics ou privés. 


\title{
Ecological economics and scientific controversies. Lessons from some recent policy making in the EEC
}

\author{
Jean-Charles Hourcade, Jean-Michel Salles and Daniel Théry \\ Centre International de Recherches sur l'Encironnement et le Déceloppement, \\ Ecole des Hautes Etudes en Sciences Sociales, Unité de Recherche Associée au CNRS no70. \\ 1, rue du 11 novembre, 92120 Montrouge, France
}

(Received 27 March 1991; accepted 4 February 1992)

\begin{abstract}
Hourcade, J.-C.. Salles, J.-M. and Théry, D., 1992. Ecological economics and scientific controversies. Lessons from some recent policy making in the EEC. Ecol. Econ.. 6: 211-233.

Contrasting the very limited scientific evidence on the forest dieback issue with the sudden adoption of policies on air pollution decided in the FRG (1983-84) and extended to the European Community (1985). we propose an interpretative framework for the real internalization process at work in what was tantamount to a social crisis for public opinion, the media and political actors. We conclude that open scientific controversies on some environmental issues (effects, causes, solutions) pave the way for some actors to use the issue for their own techno-industrial strategies quite alien to ecological constraints. In cases of very high uncertainties on impacts, it becomes impossible to apply conventional social cost-benefit analysis (SCBA) as an optimizing tool. We propose to develop economic analysis as a negotiation language and to give pride of place to the value of learning time and to the crucial role of technological pluralism as a condition for flexibility in the future.
\end{abstract}

\section{INTRODUCTION}

\section{The neo-classical background}

Despite the heterogeneous picture painted by a recent OECD evaluation (1989), the economic instruments actually implemented in environmental policies have a common feature. In line with the pigouvian tradition, environmental costs are internalized through a collective decision taken by public authorities under pressure of public opinion or thanks to

Correspondence to: J.-C. Hourcade, Centre International de Recherches sur l'Environnement et le Développement, Ecole des Hautes Etudes en Sciences Sociales, Unité de Recherche Associée au CNRS n'940, 1, rue du 11 novembre, 92120 Montrouge. France. 
the vigilance of experts. In terms of normative economics, progress towards Pareto optimality can be expected from this better accounting of collective preferences for a sound environment. However, a reverse risk of underestimating the costs of environmental protection measures with respect to productivity and growth is repeatedly underlined from Denison (1979) up to ongoing works on the costs of preventive policies in the face of the greenhouse effect (Manne and Richells, 1990). The real economic system externalizes ecological problems in its routine functioning, and the role of the economist is to try to ascertain the "optimal" trade-off between ecological costs and economic incomes (Beckerman, 1972a,b).

The environmental agenda has fundamentally changed over the past two decades. Instead of isolated cases, global issues (nuclear hazards, forest dieback, ozone layer, greenhouse gases) are now in the limelight. The initial theoretical framework is confronted with the challenge of coping with some intrinsic characteristics of these global risks. The fundamental scientific uncertainties about the complex mechanisms at work in these global issues, and even about the reality of some dangers, exacerbate the usual implementation difficulties due to threshold effects and to the irreversibility dimension. The all-pervasiveness of these global issues, together with growing popular awareness, force producers to include them in their strategic plans. These global ecological issues are no longer simply an externality that an agent must integrate because of a regulation decided by a Welfare State in the name of collective interest. They have become de facto part and parcel of technological, industrial and economic strategies, as shown by the following issues: the demise of civil nuclear programs in several countries; the CFC question; the use of environmental norms as protectionist tools; the prospects of renewed competition between energy sources triggered by the greenhouse effect debate, etc.

Economic theory has tried to follow this movement either within the framework of mainstream economy according to the findings of Henry (1974) and Arrow and Fisher (1974) on the treatment of irreversibilities as measures of the value of future information, or through alternative paradigms such as the procedural analysis of Simon (1976), as opposed to substantial rationality or the paradigm of systemics where the Earth constitutes a unique and finite world (Boulding, 1966) with co-organizational relations between biosphere and human activity (Godard, 1984). Although all these approaches are heuristically efficient, they have not, thus far, succeeded in proposing principles for public decisions as the standard theory does. Therefore, the dominant movement towards the "economics of sustainable decelopment" (Pearce et al., 1989) keeps advocating the "costbenefit mode of thinking" (Barbier and Pearce, 1990) despite the implementation difficulties. 


\section{New directions}

At a time when global issues and growing awareness tend to disseminate the demand for expertise far beyond enterprises and administrations towards lobbies, political parties and social movements, it is timely to reassess the adequacy of economists' tools in a context dominated by scientific controversies on ecological issues. In such cases, can he transfer his conventional tools out of their sphere of origin, without weakening their relevance, increasing their opacity and losing control of the resulting conclusions, up to a point where he may marginalize economic analysis in the decision-making process.

The second section concentrates on the problem of acid rain and forest dieback in Europe, considered an archetypical "encironmental crisis" to be treated as an emergency by the political sphere because of the perception by the public despite the lack of scientific proof. The reader should be warned that the debate is not dealt with extensively here. For the purpose of clarity the case studies focus on the "French" and "German" positions in the controversies; this stylization by no means neglects the role of other actors, but will enable us to concentrate on the cross-perceptions between these two extreme behaviors. Comparing briefly the energy policies in both countries after the oil shocks provides a background to the case study on forest dieback.

The third section proposes an interpretative framework of the de facto internalization process at work in a wide range of new environmental challenges characterized by the existence of open scientific controversies on the reality of dangers, on the quantitative analysis of their causes and on the relevant technical solutions.

The final section underlines the gap between this framework and the theoretical principles of conventional environmental economics. We shall then try to show the necessity for and the conditions of a drastic modification in the status of cost-benefit analysis for dealing with a wide range of environmental controversies. When conventional SCBA can no longer be applied as an optimizing tool, we propose to develop economic analysis as a negotiation language and to give pride of place to the value of learning time and to the crucial role of preserving technological pluralism as a condition for future flexibility.

BEHAVIOR AND STRATEGIES IN THE FACE OF A SUDDEN ISSUE: ACID RAIN CRISIS AND ENERGY POLICIES IN EUROPE

French and German energy strategies: a brief comparison

In all OECD countries, the adjustments following the oil shock can be disaggregated and analyzed as a mix of supply-side and demand-side 
responses. A striking paradox is that the quantitatively most important response - namely the "delinking" of energy consumption and economic growth over the period 1973-1987 - was not planned ex ante, but only recorded ex post (except for Japan, see Kalaydjian, 1988). Contrary to the supply-side responses this delinking did not result from explicit strategies, at least until the eighties.

Beyond obvious dissimilarities and different emphases given to priorities such as security, cost minimization or macroeconomic equilibrium, the responses had two common features. First they mobilized in each country those "national" assets that were conducive to the adjustments, but which had been prepared far beforehand quite independently of the sudden new context. Second, during the seventies they share a common neglect of environmental constraints (Hourcade, 1988).

After the 1973 oil price shock, France had to mobilize its existing assets without sufficient time for preparing anything else. It consistently gave priority to the external balance. The demand-side responses were not at that time seriously on the discussion agenda because decision makers relied almost exclusively on a supply culture (Puiseux, 1982). In such a context, the rapid launching of the nuclear program was readily accepted and apparently with an increasing national consensus until the Chernobyl accident, at least in the policy making spheres. From this standpoint, France is an exception in the European Community, but one must recall that it had no assets with respect to conventional energies, unlike the United Kingdom or West Germany. The Lacq gas reserves were declining without any short-term hope of discovering another major new source in France; the best of the hydro-electric potentials had already been tapped. As for coal, soon after the 1981 elections the socialist government rapidly gave up the official aim of producing 30 Mtoe/year in the eighties and planned a lowering to 10 Mtoe around the year 2000 .

Rooted in scientific tradition long before the Second World War, and in the technological potentialities set up during the development of atomic weapons, the nuclear solution was spontaneously held as a ready-made solution to be launched on a large scale (Plan Messmer) 2 years after the settlement of the dispute about the choice of nuclear technology between the Commissariat à l'Energie Atomique (CEA) favouring the French graphite-gas technology and Electricité de France (EDF) favouring the American technology (PWR pressurized water reactors). Furthermore, the nuclear choice was an industrial challenge beyond the energy policy area; it was clearly a bet on the French electro-mechanical industry becoming a world leader in the nuclear technology market. The rapid development of the program managed to overcome the anti-nuclear movement which reached its apex in 1977 at Creys-Malville and then receded (Nelkin and 
Pollack, 1980). The debate on the security issue was strengthened by the Chernobyl accident, but it has never been close to reversing the success of the nuclear lobby. More convincing have been the criticisms raised about the economic costs of the nuclear program, but it was not before the eighties that a note of caution was expressed among official circles about excess nuclear capacity.

The situation differed greatly in West Germany where the political creed "Weg com Öl" was translated into significant intervention in the energy supply system in favor of coal; it decreased from $32 \%$ of final energy consumption in 1973 to $27.5 \%$ in 1988 . After an early launch, the nuclear program was drastically reduced because of powerful protest movements. The installed electric capacity was only $21.8 \mathrm{GWe}$ in 1988 compared with 52.9 Gwe in France, despite a higher total electricity consumption in Germany (428 TWh compared with only $392 \mathrm{TWh}$ in France). But the recourse to coal and the down-turn of the nuclear program were linked to a constant and significant subsidy for national coal production in Germany more than elsewhere in Western Europe.

Contrary to the French situation, the coal industry took advantage of its economic and social importance, especially in the powerful Land of NordRheinland-Westfalen, to convince the government that it should impose upon the utility companies the signing of the 1980 "Jahrhundertvertrag" whereby they commit themselves to buy $40 \mathrm{MT}$ of national coal yearly. As a compensation for the overprice paid above the world price, the utility companies are legally entitled to add the "kohlenpfennig" to the invoice paid by electricity users. Together with the direct public subsidy paid for the coke used by the iron industry, the global cost of the national coal program amounted to 40 billion FF per year.

In fact, both countries adopted strategic behaviors that are a far cry from the rules of a pure market economy. Both the state-fostered nuclear program in France and the defense of national coal in Germany have had such deep structural effects on the whole energy sector of each country that they created some kind of irreversible process (Hourcade, 1991), not only because of the tremendous resources allocated, but also through their impact on national innovation patterns.

Whereas until the very beginning of the eighties the existence of drastic divergences between France and Germany regarding the nuclear risk did

\footnotetext{
1 The national strategy is so difficult to reverse that Mr Kohl did not hesitate to promise in April 1989 that the coal subsidy policy would not be cancelled after 1995 despite the EEC rule.
} 
not lead to direct confrontation within ECC regulations, the acid rain issue created a totally different picture. Because of the internationalization of the car market and of the increasing role of the Europcan Community Commission at the time when the "Unified Market" perspective was decided, it became impossible to neglect the differences between countries for determining national behaviors and strategies (Salles, 1989).

\section{Strategies and behaciors in the face of a sudden encironmental debate}

The sudden transformation of a long and complex scientific debate into a politically sensitive issue

Until the seventies, $\mathrm{NO}_{x}$ and $\mathrm{SO}_{2}$ emissions were mainly perceived as causing local damage to human health and to monuments directly exposed to urban traffic and to industries. The solution consisted of building tall chimneys in order to dilute emissions according to the prevailing air quality standards. The phenomenon of "long-range" pollution (now called acid rain) only became common knowledge after the Stockholm conference of 1972 which admitted that thousands of lakes in Scandinavia and Canada were 'dead' because of acidification. This transboundary pollution raised legal issues, although there was no doubt of the identity of the main activities causing acid rain, namely large combustion plants for both $\mathrm{SO}_{2}$ and $\mathrm{NO}_{x}$ and cars for $\mathrm{NO}_{x}$ emissions. After the vast OECD "Cooperative Technical Program to Measure the I ong Range Transport of Air Pollution", a Convention was signed in Geneva (1979) on the initiative of the United Nations Commission for Europe. A group of countries committing themselves to reduce by $30 \%$ their overall emissions was created 5 years later in Ottawa and institutionalized in 1985 by the Helsinki Protocol. At that moment, the link between acid rain and forest dieback was not central to the discussions on acid rain, and other pollutants (hydrocarbons, heavy metals, etc.) were also considered as contributing to forest dieback. But the situation changed very quickly in the early 1980s in Germany where concern about the "Waldsterben" phenomenon came suddenly to the limelight on the political agenda. Most remarkable is the pace of this transformation. Soon after two German scientists, P. Schütt (München) and B. Ulrich (Göttingen), stated that such a link exists (and despite disagreement between them about the explanatory factors) the information rapidly leaked out from the scientific sphere to the mass media. The part played by the "Green Party" in German political life led to a large public debate and to the majority feeling that reaching decisions had become an emergency (Roqueplo, 1988a). In order to circumvent the political crisis, the German government quickly adopted more severe norms on polluting emissions for thermal plants and for cars (Scimeni, 1987). 
The rapidity with which the decisions were taken (Salles, 1990) is stressed here. The crisis had exploded in the media only in 1982-1983; more severe rules were established for thermal plants in a new version of the German air protection regulation (T-A-Luft) as early as 1983. In July 1983 the government produced its first draft of a clean car regulation, which was finally accepted by the various economic partners in the summer of 1984. The debate immediately took a European dimension since such norms could be perceived as non-tariff barricrs to free trade and competition, precisely at a time of progress towards a Unified European market.

The context of on-going scientific controcersy

The core of the scientific debate lies in the weight to $r e$ attributed to each potential air pollutant. According to the answers, the technological challenge of reducing the emissions will be directed to completely different industries. Even by limiting the analysis to the simplified models used at that time, Barré (1985) could summarize as follows three alternative hypotheses on the causes and on the priorities for action.

If soil acidity (mainly due to $\mathrm{SO}_{2}$ emissions, and secondly to $\mathrm{NO}_{x}$ ) is the main mechanism responsible for "forest dieback", there are two hypotheses depending on whether or not there is an aggravating synergy with ozone beyond a threshold soil acidity level yet to be determined. If such a level is proven, it may be sufficient to curb $\mathrm{SO}_{2}$ by placing restrictions mainly on thermal plants and other large industrial sources (boilers). It is only if photo-oxidation and soil acidity synergy takes place at a low threshold level that $\mathrm{NO}_{x}$ and $\mathrm{SO}_{2}$ emissions will have to be limited jointly. But, according to a third hypothesis, the level of photo-oxidants (mainly ozone) in the troposphere is the causal link whatever the level of soil acidity. The responsibility must be borne by $\mathrm{NO}_{x}$ and also VOC (volatile organic compounds) emissions, which modify the level of these photo-oxidants, and the abatement policy must focus on the transport area alone, and mainly the car industry.

\section{$A$ difficult and conflictual settlement of the issue}

From the outset it was obvious that the industrial consequences of these controversies would be very unequally distributed among the different actors in the negotiations. Whereas the German fossil fuel based utilities were hard hit by the antipollution costs, the adjustment effort for the clean car was far less difficult for German car industries than for the French. This dissymmetry requires a more detailed techno-industrial analysis. 
$\mathrm{SO}_{2}$ emissions from electricity production and other fixed plants

The ECC directive concerning fixed facilities consists of a double mechanism. At first the Europeans decided on the allocation to each country of a scheduled global emission quota. Secondly, they referred the standards for each new plant to the notion of the Best Available Technology Not Entailing Excessive Costs.

A priori, France could have gained an important advantage from an exception made in favor of thermal plants that are operated less than 2200 $h$ per year. It is precisely the case for those fossil fuel plants that are operated only during the winter peak-load created by the seasonal demand for electric heating (nuclear plants cannot produce profitably for such short periods). A priori, it might have become easier to present nuclear electricity as a "clean" energy and to increase electricity exports thus relieving the overcapacity problem. Although these exports did increase in the second part of the eighties, the accident at Chernobyl rendered this line of argument unsustainable in Western Europe.

After the 1983 promulgation of a new version of the air pollution regulation (the T-A-Luft), Germany launched a desulfuration program costing US $\$ 12$ billion over 5 years. Though $\mathrm{NO}_{x}$ emission reduction was also dealt with in the above directive on fixed facilities, the $\mathrm{NO}_{x}$ emissions were central to a separate directive on cars.

$N O_{x}$ and the "clean car" directive

In Germany, the catalytic technology for cleaning automobile exhaust gases had already been mastered for sustaining the export drive of cars to the American market. Quite naturally all high-powered German cars were previously equipped with electronic injection, which incidentally is a precondition to the catalytic technology. Thus the additional cost of a clean car was quite bearable for this upper part of the market. Moreover, Bosch held a monopoly on the mechanical part of the catalytic exhaust system. Last but not least, the image of a device acting as a filter was quite easily grasped by the general public as a visible contribution to cleaning the air and thus to protecting the forests.

The path followed was completely different in France. As stated above, energy savings were consistently adopted as a direct technological target by the car industry, whereas the limitation of polluting emissions was viewed mainly as a side-effect of this energy efficiency. Then the French car industry, as well as the Italian, were reluctant to accept the proposed European regulation because it imposed a series of intertwined setbacks on their technological trajectories and consequently on their competitiveness.

Firstly, these industries did not master the three-way catalytic exhaust pipe, a technology developed in the US for the prevention of urban smog. 
In 1983 this technology was the only one available to meet the stringent standards adopted by the German regulation. The French administration suspected it would put its market in a subordinate position to German firms such as Bosch which possessed a monopoly on the mechanical part of the injection system.

Secondly, the catalytic technology adds only $2-4 \%$ to the cost of a high-powered car that already possesses the electronic injection system, whereas the price increase due to the two innovations could range up to $10 \%$ for low-powered cars. The share of small vehicles in the total market is $67 \%$ in France and only $37 \%$ in Germany.

Thirdly, the "three way catalytic exhaust technology" is not compatible with lean burn technologies, which were designed specifically to save energy beyond the readymade saving already derived from the speed limitation policy. If the impact on air quality obtained as a side-effect of energy saving is deemed to be no longer sufficient, there is every reason to believe that an explicit R\&D effort could carry the lean-burn trajectory much nearer to the performance of the catalytic technology concerning air pollutants. That is why the opposition of the French firm Peugeot to the German proposal of 1983 is easy to understand. It would render the lean-burn option obsolete by regulation without giving sufficient time for exploring the potential for improving the lean-burn option. Moreover, the implementation gap due to behavioral and infrastructural constraints could decrease the expected performance of the catalytic option comparatively more.

As early as 1984, scheduled targets for $\mathrm{NO}_{x}$ emission standards for cars were suggested by the European Commission. Diverging views soon opposed the northern part of Europe (FRG, the Netherlands, Denmark, Luxembourg) on one side, and other countries (France, Italy, the United Kingdom) on the other side concerning how to apply these norms, and whether a rapid decision would be relevant. The choice of strategy was linked to the emergency argument. Was it possible to wait for a wider variety of techniques, or was it urgently needed to generalize the cleanest available technique as decided by the FRG?

In July 1984, Germany unilaterally adopted national norms that implied that a three-way catalytic exhaust pipe has to be used together with an electronic injection system; both elements would cost around 800 ECU per car. Two months later, the European environment ministers decided to enforce emission standards differentiated according to the cubic capacity category of cars, and in March 1985 a timetable was decided upon. In June 1985 , norms were adopted in a directive of the ECC that was signed in December 1987 within the framework of the "Unique Act", and adopted in 
June 1988. 2 Consequently, unleaded gasoline had to be available everywhere in Europe by October 1989.

Some paradoxes in the negotiations on acid rain

Whereas German pressure during the ECC negotiations resulted from the dynamics of its internal political scene, the French rearguard action resulted from three factors (Le Bail, 1985; Valroff. 1985).

(a) Firstly, the fact that, thus far, French forests had been much less degraded than in other countries except for places in the Vosges and the Jura. Likewise, lake acidification had not been a major concern. This relatively satisfactory situation can be explained by the fact that France is sheltered from dominant winds from the Atlantic Ocean and that its domestic emissions remain relatively moderate. ${ }^{3}$ This rather optimistic picture is supplemented by the fact that $\mathrm{SO}_{2}$ emissions had decreased by more than 60\% between 1973 and 1985 .

(b) Secondly, awareness that the French global emission level is and will remain lower than that of other countries. As early as 1982, a study by The Beijer Institute presented at the Conference on the Acidification of the Environment in Stockholm reported that, according to the most likely scenarios, France and Sweden would be the only countries likely to reduce their $\mathrm{SO}_{2}$ emissions by the year 2000. A study (CITEPA, 1989) ${ }^{4}$ confirms the favorable prospects of a decrease of $\mathrm{SO}_{2}$ emissions by $32 \%$ between 1985 and 2000 . Thanks to the nuclear program and the delinking of energy and growth, a positive but involuntary side-effect on $\mathrm{SO}_{2}$ emissions had been observed.

(c) Thirdly, a background factor must be taken into account; namely the differences in the collective expectations of ecological risks and in the interpretations of scientific knowledge. The exploding public debate on the acid rain issue in Northern Europe resulted within 3 years in a double transformation of scientific hypotheses into well established facts: firstly a direct link between acid rain and forest dieback, secondly a focus on the car as the main source responsible. The southern European position, on

\footnotetext{
T The French retractation from 20 July 1988 until November 1988 denounced a case of distortion of free trade in the European market, namely the tax incentives decided in The Netherlands for cars in conformity with American norms.

3 As a consequence of low population and industrial densities. the $4.4 \mathrm{t} / \mathrm{km}^{2} \mathrm{SO}_{2}$ emissions recorded in France were much below the $14.1 \mathrm{t} / \mathrm{km}^{2}$ in West Germany, $17.4 \mathrm{t} / \mathrm{km}^{2}$ in the United Kingdom, $10.2 \mathrm{t} / \mathrm{km}^{2}$ in Italy and $37.0 \mathrm{t} / \mathrm{km}^{2}$ in East Germany (1986).

" CITEPA stands for "Centre Interprofessionnel Technique d'Etude de la Pollution Atmosphérique", Paris.
} 
the contrary, relied on the fact that the relationships between emissions of specific atmospheric pollutants and the "death" of forests remain controversial ${ }^{5}$ (Bonneau and Elichegaray, 1990).

Paradoxically, a section of French industry was hurt by environmental concern, of which the energy sector (decrease of $71 \%$ in emissions from power stations) and the manufacturing sector (decrease of $58 \%$ ) could argue to have made an important effort including increased end-use energy efficiency, establishment of norms for $\mathrm{SO}_{2}$ contents of fossil fuels and an increase in natural gas share. However, emissions from combustion plants, which had been increasing up to 1979, dropped sharply only after the nuclear power plants started working ${ }^{6}$. The French administration drew no other advantage from this positive side-effect, since nuclear power was to remain the symbol of an ecologically dangerous technology in most developed countries.

\section{ACTUAL INTERNALIZATION PATTERN: A TENTATIVE INTERPRETATIVE FRAMEWORK}

The forest dieback case study demonstrates a sharp contrast between the number of scientific uncertainties and the rapid and arbitrary internalization of a still obscure environmental issue within industrial strategies. The time-scale element is at the center of this contradiction (Salles, 1990) because the artificially created emergency argument is used to circumvent the mounting crisis. We propose an interpretative framework for a wide range of environmental issues presenting the same features, because we think that they are to be found far beyond our case study.

\section{Decisions made under controversy and environmental crisis}

European producers had to comply with the new regulations that wcre decided in order to defuse the crisis outlook given to the forest dieback issue by the media, despite a lack of well-established scientific knowledge about its real mechanisms. Some years later, the scientific community is still not really able to provide a satisfactory model of the forest dieback

\footnotetext{
5 Forest observation systems were established quite recently (1981 in the FRG). Only in 1983 did France launch a program called DEFORPA (standing for, in French, Forest Decay Attributed to Atmospheric Pollution).

${ }^{6}$ According to CITEPA, emissions were $3340 \mathrm{kt} \mathrm{SO}$ and $1820 \mathrm{kt} \mathrm{NO}$ in 1980 and decreased to $1230 \mathrm{kt} \mathrm{SO}$ and $1610 \mathrm{kt} \mathrm{NO}_{x}$ in 1988, though the emissions from mobile sources increased steadily by $20 \%$ despite a $27 \%$ decrease in the average consumption per kilometer of new French cars between 1975 and 1987.
} 
phenomenon to economic and political decision-makers (Bonneau and Landmann, 1988). As a matter of fact, most scientists have given up monocausal explanations and now consider multifactoral approaches. The causes currently studied include both permanent sources such as soil acidity due to atmospheric pollutants (usually called acid rain even if it includes dry deposits), acid fog (for its direct action on leaves and needles), photo-oxidation (PAN and ozone due to the anthropogenic emissions of $\mathrm{NO}_{x}$ and volatile organic compounds), some forestry practices, especially spruce monoculture, and some climatic events (Pearce, 1990).

The uncertainty element can be much larger with respect to impacts, as is the case for nuclear risk or even for the greenhouse risk linked mainly to fossil fuels. We are then clearly confronted with risks that are immeasurable by nature.

The first conclusion is that we need the concept of scientific "undecidability", which can be used as a "space for maneuver" in a negotiation process, for explaining the behavior of actors with regard to this type of environmental controversy. We propose to call undecidability any situation in which, at a given state of knowledge, a scientific issue remains controversial because experimental data or theoretical tools are lacking (and are expected to remain lacking for the foreseeable future).

The urgency of decisions in the context of political crisis constrains both the rhythm and the content of choices. When it takes too much time for science to explain phenomena and to elaborate more appropriate technologies, it is tempting to try and to solve the socio-political crisis by offering a set of technical solutions based on the subset of existing technologies capable of reconciling political and economic interests involved in the environmental debate. ${ }^{7} \mathrm{~A}$ possible consequence is the occurrence of "reversed risk" configurations (Roqueplo, 1988b), defined as situations in which, for some actors, the ecological danger is exceeded by the industrial risk generated by a particular solution. In the present case, the French firms that were hit by the European norms could argue that German policy had selected precisely that unproven scientific hypothesis that best served their own economic advantage. The opportunity for industries to use a "space of scientific uncertainty" in environmental issues as a "space for maneuver" for their strategic purposes can be fully understood only by symmetrically taking into account the time and risk constraints on the technological innovation element.

$\overline{7}$ On the role of socio-technical networks in innovative processes, see Callon et al., 1986. 
The peculiar rationale of innocation with regard to encironmental issues

The strategy of each actor can be viewed as an attempt at gaining an advantage in the redistribution of the "use rights" and responsibility rules involved in any decision concerning environmental standards. In modern economics, the global environment belongs to the wide category of public goods; to allow an individual producer (the legal ownership does not matter here) to take the risk of affecting environmental quality is equivalent to a distribution of "primary property rights". ${ }^{8}$ Then the redistribution of these rights resulting from any modification of the standards modifies the state of competition between firms, local or national authorities, and groups of citizens (Bromley, 1978).

As shown earlier, political dynamics may artificially create the need for a decision in an emergency, which precludes leaving sufficient time to proceed from research to truly innovative solutions. In such a context, urgent answers must be found from the available existing technologies developed long before. Furthermore, "clean technologies" (such as catalytic exhaust pipes, desulfuration processes for large plants, or security systems in nuclear power plants, etc.) are very specific cases of innovation because they increase production costs without bringing any additional private benefit to the final consumer. Experience shows that the real behavior of most private consumers diverges from their expressed ecological preferences as "citizens". Consequently, the producer cannot reasonably expect to rely on self-maintained markets for antipolluting or ecologically sound technologies ${ }^{9}$ in the absence of a transformation of national or international regulations. Besides he needs to anticipate these regulations not so much because of the ecological costs and the antipollution costs usually quoted in the literature, but because of the risk of "strategic revision cost" (i.e., the cost of redefining whole parts of the industrial strategy) if his innovation strategy is not coherent with the standards adopted. A case in point is the "three-liter-car" strategy of the French car industry. Similarly, another major accident could render the nuclear program totally unacceptable and put into question most of the huge innovation and industrial effort already expended.

\footnotetext{
${ }^{8}$ This distribution must be dealt with in relation to the notion of the legitimacy system, a subject matter extending much beyond economics and our article (see Laufer and Paradeise, 1989).

9 The failure of real markets to devise satisfactory regulations for environmental issues was commented on in the seventies (see, for example, Ruff, 1970).
} 
In order to protect themselves against such potential "strategic revision costs", microeconomic agents logically adopt a behavior that tries:

- to negotiate a framework of new rules minimizing the adjustment costs or imposing these costs equally on their competitors;

- to preclude any decision that forces them to go beyond their technological knowledge and capability; ${ }^{10}$

- to legitimize their arguments on the basis of the present state of knowledge.

Industrial firms could refrain from innovating should there be repeated cases of "reversal of risks", whereby their efforts are arbitrarily made obsolete by environmental crises in ways that cannot be rationally anticipated. A flexible balance between economic and ecological constraints in the long term could thus be rendered impossible by maneuvers towards deriving a monopolistic advantage from new regulations, and for inhibiting alternative innovative approaches.

\section{Environment serving as an instrument for other industrial strategies}

The sequence of processes described could be stylized as follows. First, an environmental problem is kept within the sphere of certain scientific circles as long as the general public is not too excited about obtaining a quick answer. A certain degree of scientific uncertainty cannot be avoided as long as it deals with complex issues. The most sensitive situation occurs when the media take hold of the issue before the whole array of complex causes has been sufficiently explored by scientists. Then simple explanations may tend to be selected prematurely by the media if scientists are not able to resist such a shortcut. Indeed, the media, together with politicians, are apt to dictate their own preference for simple and ready-made answers as soon as the public believes that we are on the brink of an ecological disaster. For obvious reasons the media dislike complex scientific puzzles and prefer to transform them into an urgent environmental crisis to be solved by strong political will. The scene is then ready for some actors to push their own strategic interests. This was clearly the case when the environmental crisis whipped up by the media served as the instrument for one specific car industry lobby to push in favor of its own ready-made technology. It may also be temptation for supporters of nuclear energy to attempt a comeback owing to the greenhouse risk.

Quite different time scales have to be taken into account when analysing the three steps of the sequence. Its main feature is that neither the

$\overline{10}$ Apart from some exceptions (in the USA and Japan), these rarely succeed. 
environmental issue for science, nor the environmental-related crisis set on the political scene by the media, nor the truly innovative technological responses have the same time-horizon. In the specific context of the acid rain issue, the cautious behavior of waiting until one better understands which policy options should be chosen was superseded by a combination of the media and political and industrial actors advocating the use of the 'emergency' argument for adoption of a ready-made answer. Consequently, the main problem for the social scientist is to understand how some actors wrongly internalize environmental concerns when the implementation of a substantive rationality (dependent on scientific advances in ecologically complex issues) is impeded by the crisis tempo dictated by very powerful actors.

\section{A PLEA FOR THE ADAPTATION OF ECONOMICS TO ENVIRONMENTAL CON- TROVERSIES}

\section{Economic analysis and its limitations}

To what extent can the professional economist rely on his usual tools (expected value of external costs, rational expectations, learning process) if he wants to resist such shortcutting of controversial scientific issues and adhere to informed policy-making? The key point here is how to use the social cost-benefit analysis (SCBA) framework. On the side of the "benefits" of environmental protection, it requires the capacity to assess, for instance, the costs of forest dieback or of a nuclear accident both in macroand microeconomic terms. "The limits to this approach have often been emphasized: ${ }^{12}$ can forest losses be assessed (at what prices, on which markets)? How can one assess the value of a forest as a multiservice supplier (landscape, leisure area, atmospheric pollution filter, oxygen producer)? How can the general effects on human health be estimated? Is it relevant to apply the theory of probability to the case of a nuclear accident? How do we deal with systemic relationships where cause and effect are difficult to separate?

These practical limits to the conventional approach point to some reasons for the well perceived implementation gap between theory and practice in economics. But by themselves they do not really put the whole framework into question since it is (in principle) always possible to value

\footnotetext{
1 For example, concerning a hypothetical nuclear accident, Vlies and Vlist attempted to estimate the macroeconomic loss related to GDP in The Netherlands, whereas Ströbele assessed the effect on the average costs of electricity generation (papers presented at the IAEE Tenth Annual International Conference, 1988).

12 Beckerman (1972a) and Kapp (1972) debated these limitations.
} 
costs and benefits by way of parametrization and to develop research for more knowledge.

In the standard neoclassical framework the sequence of analytical steps is clearly identified:

- firstly, reveal the preferences of agents through their willingness to pay for the limitation of an environmental damage;

- secondly, scientifically determine the share of responsibility of each specific economic activity for the ecological damage under analysis;

- then quantify the relationships between each economic activity and each ecological impact;

- and, finally, aim at internalizing the social costs through taxes, emission permit systems, norms, etc., under the control of a legitimate authority (local administration, regulatory commissions, national governments or international institutions).

In this framework, the internalization of externalities always results in "a plus" for notional economy, progress towards the Pareto optimality under perfect information, but often in "a minus" for the real economy, since a new monetary cost is now imposed on some activities. Economic analysis has a substantial normative function for providing tools (economic calculations and institutional solutions) for choosing an optimal trade-off between social damage and pollution control costs.

\section{Complications in the relationship between economics and ecology}

The acid rain case shows the necessity of going beyond the conventional framework and of setting guidelines on the research agenda of "ecological economics", viewed as an attempt to understand better the relationships between ecology and human activity. Their complexity, as exemplified by the acid rain issue, may go beyond what can realistically be coped with using the conventional toolbox for the following reasons.

(a) The concept of "decision under controversy" would be more appropriate than the conventional concept of "decision under uncertainty". The present and future "states of the world" are not only largely "unknown", but "controversial"; there are several competing scientific theories for describing the possible states of the world and the probability distribution of these states depends on the decisions taken today, which depend on a choice (at least implicit) between these theories. As no industrial commitment can be taken without a certain stability of the institutional context (norms, laws, economic instruments), there is obviously pressure to converge on that subset of theories that seems the most able to legitimize a minimum agreement. The competition between theories is then part and parcel of the strategy of each economic actor, but with no guarantee that 
the occasional common agreement on internalization procedures will later prove ecologically and economically founded.

(b) The agents' preferences for a safe environment are not often mainly linked to a direct perception of a "state of nature". Rather, the works of the scientific community and the experts are used by the media to shape public opinion. The level of concern in the face of the acid rain problem was very low in West Germany until 1983, when the media popularized the view that the forests were on the verge of death.

The history of the "Waldsterben" concern is in fact an archetype of a whole range of cases. Whereas the neighbors of a motorway often protest against the disamenities due to noise and demand protection walls, nobody would spontaneously complain about ozone layer depletion or the greenhouse effect. Citizens become concerned when warnings by scientists are brought to their awareness by journalists and later by politicians.

(c) For these two reasons, the search for the appropriate institutional process for dealing with the economy/ecology interface cannot be focused only downstream, assuming a well shaped distribution of costs and benefits and a straightforward determination of the cause/effect relationships; the institutional context partly determines the cognitive process, and also the resolution of controversies that permits the beginning of collective action.

(d) The core of the matter is less the problem of internalizing the external costs with a given toolbox of pre-existing antipollution techniques than to trigger a new innovative dynamic. In the case of a decision under controcersy, the learning process can be prematurely cut short by a decision that may shape the innovation process towards irreversible paths, and scientific knowledge may later prove that such a premature decision was suboptimal.

Do all these limitations disqualify economic sciences from providing normative tools, since any calculation reflects only a transitory balance of powers? Certainly the legal sciences, the sociology of institutions, and the political sciences are needed for studying the management of these controversies and of the media process between experts, policy makers and public opinion. It would, however, be dangerous to conclude that a theoretical foundation for collective action in the face of ecological risks could be provided without any reference whatsoever to economics. Even if conventional cost-benefit analysis cannot be satisfactorily carried out "ex ante", any significant decision to tackle environmental problems will de facto entail "ex post" costs in the form of direct costs, of transformation of behaviors and of innovation patterns. In the face of the equity issues unavoidably raised by this social process, no action can be legitimate unless these impacts are assessed, which both implies the use of some kind of cost-benefit analysis and a reconsideration of its status. 
Decelopments in cost-benefit analysis

Fraught with too many uncertainties and controversies, social cost-benefit analysis (SCBA) cannot measure unequivocally the social efficiency of choices. After recognizing this limitation, Henry $(1984,1989)$ shows that SCBA can be used as a language for negotiation; SCBA forces each actor to express explicitly his preferences and anticipations for the future states of the world.

This challenge is the origin of recent efforts to build an economics of "sustainable development". Barbier (1990) sketches current trends in the field of environmental economics as passing from a conventional approach concerned with the optimal allocation of economically valuable and exhaustible resources to a more comprehensive analysis of the utility yielding services of the environment - material and energy inputs, productive recycling of wastes, and ecological functions, mainly the preservation of climates and of essential ecological cycles and balances. For that purpose, he proposes a very stimulating economy/ environment model that tries, on the line of Pearce et al. (1989), to account for the total economic lalue provided by all the functions of an environmental asset.

This intellectual framework is certainly useful for grounding the legitimacy of a collective action dealing with the environment in terms other than a pure stock of resources. More specifically it calls attention to the risk of an irrelevant extension of the pure logic of replacing natural capital stocks when some irreversible loss of an ecological function is at stake. However, our case study illustrates the practical inability of assessing in due time the real economic value of all the functions of an environmental asset, especially for controversial issues. The economist's conventional toolbox cannot be applied when the scope of uncertainty on some parameters is too great. Admittedly, the economist can calculate an infinite number of social cost-benefit simulations related to an infinite number of scenarios and theories, but how can he reach a conclusive agreement among the concerned parties. The Fifth Congresso Brasileiro de Energia held in Rio de Janeiro in November 1990 also illustrated that any attempt to measure the cost-benefit balance of the collective services provided by the Amazonian forest will, for the time being, only foster a regressum ad infinitum of controversies with the severe risks of too belated an action.

Another way out of this apparent deadlock is to push a step further the new vistas opened by the "option value" concept. Barbier and Pearce (1990) referring to Bishop (1982) demonstrated that, under conditions of supply-side risks, society would be willing to pay a sum to avoid future risks. This sum is an option price which is greater than the expected social loss of welfare due to all these risks. Along this line, Barbier and Pearce 
(1990) then note that the case of climatic change involves pure public risks and intergenerational concerns, and they propose an analytical framework encompassing the issues of sustainable development economics. In a riskadverse society, taking into consideration some degree of intergenerational solidarity, compensation must be paid today for long-term losses of welfare. "If we knew the actual damage, $Y$, associated with climatic change, ${ }^{13}$ we could set aside a sum of money, $X$, today which would grow at some interest rate, $r \%$, to be equal to $Y$ in the relevant future year, that is $Y=X(1+r)^{t}$ ". But they point out immediately that "as we do not know $t$ or $Y$, the computation of the required compensation cannot be made" and they call for a proxy in the form of the sum that current generations would be willing to pay to prevent future risks. Though Barbier and Pearce admit that "low-probability, high-loss events" such as natural disasters or climatic change render "extremely difficult" the estimation of the option price, they suggest extending some results, such as those based on individuals' self-insurance through purchasing safer housing in California, an earthquakeprone area. However, could such attempts overcome the uncertainties on some items of an environmental SCBA that are bound to be much bigger than the risk-adverse premium when dealing with a controversial issue?

\section{Learning-time as a criterion for decision-making}

We would like to propose a more drastic departure from the conventional practice of SCBA when controversies are involved concerning possible irreversible (or very costly) dangers. For obvious reasons, setting a target in order to take recourse to the cost-efficiency approach will often prove an equally unrealistic aim. A better ground for economic negotiation around environmental issues could be found in choosing as a key parameter the learning time to be gained by policies in the face of a large and controversial environmental danger. Rather than evaluating "fuzzy" benefits in the very long term, the learning time criterion requires the ability to discuss directly a reference level of danger (for instance, an unacceptable GHG concentration or of nuclear waste accumulation) that is estimated to be met in a computable time horizon if status quo policies are maintained, and to rank the alternative policy options as a function of time gained before such levels are met. The economic trade-off implies a value to this gain of time, which is an additional delay for planning more informed policies.

$\overline{13}$ The same is true more generally with other global ecological risks. 
In this decision model (Hourcade, 1991) the value of time encompasses both the risk-adversity premium and the value of new information. What is proposed here is, in fact, to change the objective function of the SCBA, to give up the attempt of any long-term optimization procedure, and to focus on dimensions of alternative policies such as (a) the costs involved in gaining learning time by curbing the rate of accumulation of an environmental hazard; (b) the positive economic consequences of preserving, or even augmenting, technological pluralism as a flexibility factor for future choices.

This approach carries two advantages with it. Firstly, it focuses the negotiated agreement on the level of "ecological risk/caution" and on the willingness to pay for it without prejudicing the final settlement for a wide set of controversies. Secondly, it provides a criterion for analysing the comparative efficiencies of institutional instruments. The latter should be viewed not so much as a means of internalizing calculated environmental costs, but rather as a means of expressing the collective preferences for caution and flexibility (Favereau, 1989).

CONCLUSION: AN INSIGHT INTO THE INSTITUTIONAL INSTRUMENTS FOR ENVIRONMENTAL POLICIES

Along this line the institutional arrangements must be conducive to a triple role:

(a) change the current practices with the existing equipment, provided that the selected incremental innovations do not cost more than the value of the learning time;

(b) determine how to signal clearly the long-term risks to economic agents so that consumers, infrastructure designers, and investors are guided in the build-up of their long-term anticipations;

(c) avoid premature commitment to a technological solution or to an institutional option that could later prove too burdensome and rigid.

It is beyond the scope of this article to deal extensively with the dispute on the relative advantages of norms, taxes, polluting rights, subsidies or other instruments. Let us only stress that the learning time criterion is in conformity with conventional wisdom that the economist should avoid upsetting the current equilibrium between competing products and techniques, and should rather safeguard some degree of plurality of options and the diversity of research and development approaches. This plea against too direct an interference with technological pluralism advocates not only the use of economic instruments in the conventional sense of this word (taxes versus norms, for instance), but still more the recourse to flexible institutional arrangements. In the case of car emissions, either a tax 
could be flexibly adjusted according to new information or an equivalent flexibility could be achieved through speed limitations. Moreover, direct action with available techniques can be perfectly coherent with the learning time criterion in the three following cases: perfect information (the value of learning-time is zero), risks of irreversibilities, and common agreement between actors for defining the "best available technology".

The challenge facing ecological economics is to balance the need for a certain degree of institutional stability for the development of action and the danger of too irreversible an interference with the complex and fragile dynamics of technological innovation. To put it in the words of the "sunspot models" (Azariadis and Guesnerie, 1986), policy-makers should be less worried about assessing unmeasurable costs and benefits, and more worried about preventing the necessary coordination of anticipations from evolving into a prematurely closed technical space because of the transient dominance of one "theory" about the future. Among the works on flexible regulations or innovative formulas of economic incentives, let us quote here the proposition of "environmental bonds" which allow the accounting of uncertainties by measuring the difference between two values: "one associated with the least potentially surprising but most appealing outcome and the other with the least potentially surprising but the most unappealing outcome" (Perrings, 1989; Costanza and Perrings, 1990). This approach cannot be viewed as a ready-made solution, but gives a very stimulating illustration of research on the way to collective decisions about controversial futures. Priority must be given to this type of research if we are to succeed in advocating that a certain degree of technological pluralism is a cornerstone for reorienting towards sustainable development.

\section{ACKNOWLEDGEMENTS}

This work was financed by a research grant from the Interdisciplinary Research Program on the Environment (PIREN) within the Centre $\mathrm{Na}$ tional de la Recherche Scientifique (CNRS). This paper benefited from the comments of three referees whose remarks could not be entirely included, but gave enlightening advice for further research. Any fault or omission remains the sole responsibility of the authors.

\section{REFERENCES}

Arrow, K.J. and Fischer, A.C., 1974. Environmental preservation, uncertainty, and irreversibility. Q. J. Econ., 88(2): 312-319.

Azariadis, C. and Gucsncric, R., 1986. Sunspots and cycles. Rev. Econ. Stud., 53: 725-737. Barbier, E.B., 1990. Alternative approaches to economic environmental interactions. Ecol. Econ., 2: 7-26. 
Barbier, E.B. and Pearce, D.W., 1990. Thinking economically about climate change. Energy Policy, 18: 11-18.

Barré, R., 1985. Les pluies acides en Europe. Futuribles, 89, Juin.

Beckerman, W., 1972a. Environmental policy and the challenge to economic theory. In: Political Economy of the Environment. Problems of Method. EPHE and Mouton and Co., Paris. 240 pp.

Beckerman, W., 1972b. Economists, Scientists and Environmental Catastrophe. Oxford University Press, Oxford.

Bishop, R.C., 1982. Option value: an exposition and extension. Land Econ., 58: 1-15.

Bonneau, M. and Landmann, G., 1988. De quoi la forêt est-elle malade? Recherches, 205.

Bonneau, M. and Elichegaray, C., 1990. Acidic precipitation research in France. In: A.H.M.

Bresser and W. Salomons (Editors), Acidic Precipitation, Vol. 5: International Overview and Assessment. Springer-Verlag, Berlin, pp. 307-334.

Boulding, K.E., 1966. The economics of coming spaceship Earth. In: H. Jarret (Editor), Environmental Quality in a Growing Economy, John Hopkins Press, Baltimore.

Bromley, D., 1978. Property rights, liability rules and environmental economics. J. Econ. Issues, 12: 43-60.

Callon, M., Law, J. and Rip, A. (Editors) 1986. Mapping the Dynamics of Science and Technology. McMillan Press, London.

CITEPA, 1989. Evolution des émissions de polluants atmosphéri-ques en France 1980-1988. Etudes Documentaires No. 92.

Costanza, R. and Perrings, C., 1990. A flexible assurance bonding system for improved environmental management. Ecol. Econ., 2: 57-75.

Denison, E.F., 1979. Accounting for Slower Economic Growth - The United States in the 1970's. The Brookings Institution, Washington, DC.

Dupuy, J.P., 1989. Convention and Common Knowledge. Rev. Econ., 41(2).

Favereau, O., 1989. Valeur d'option et flexibilité: de la rationalité substantielle à la rationalité procédurale. In: P. Cohendet et P. Llerena (Editors), Flexibilité et Information. Economica, Paris, pp. 121-182.

Godard, O., 1984. Autonomie socio-économique et externalisation de l'environnement: la théorie néo-classique mise en perspective. Econ. Appl., 37(2): 315-345.

Godard, O. and Salles, J.M., 1991. Entre nature et société, les enjeux des irréversibilités dans la construction économique et sociale du champ de l'environnement. In: R. Boyer, B. Chavance and O. Godard (Editors), Les Figures de l'Irréversibilité en Économie. Editions de l'EHESS, Paris.

Henry, C., 1974. Investment decisions under uncertainty: the irreversibility effect. Am. Econ. Rev., 64.

Henry, C., 1984. La micro-économie comme langage et enjeu de négociation. Rev. Econ., 35.

Henry, C., 1989. Investment projects and natural resources: economic rationality in Janus' role. Ecol. Econ., 1 : 117-135.

Hourcade, J.Ch., 1988. Forecasting and decision on major technology programs; methodological reflections on recent forecasts of the French energy transition. In: Eighth Int. Symp. Forecasting, Amsterdam, June 12-15, 30 pp. (unpublished).

Hourcade, J. Ch., 1991. Calcul économique et construction sociale des irréversibilités. In: R. Boyer, B. Chavance and O. Godard (Editors). Les Figures de l'Irréversibilité en Économie. Editions de l'EHESS, Paris.

Kalaydjian, R., 1988. Calcul économique et principes de politique énergétique, étude des codéterminations à partir d'une comparaison France-Japon. Thèse de doctorat EHESS, Paris, 370 pp. (unpublished). 
Kapp, K.W., 1972. Social costs, neo-classical economics, environmental planning. In: Political Economy of the Environment. EPHE and Mouton, Paris, pp. 113-125. (A reply to Beckerman, 1972a, pp. 103-111.)

Laufer, R. et Salles, J.M., 1988. Le management des entreprises face au risque majeur. Rapport pour le Groupe de Prospective du Ministère de l'Environnement, 350 pp. (to be published).

Laufer, R. and Paradeise, C., 1989. Marketing Democracy, Public Opinion and Media Formation in Democratic Societies. Transaction Books.

Le Bail, G., 1985. Rapport sur les formes de pollution atmosphérique à longue distance dites pluies acides. Office Parlementaire pour l'Evaluation des Choix Scientifiques et Technologiques, Assemblée Nationale, Paris, $390 \mathrm{pp}$.

Manne, A.S. and Richels, R.G., 1990. $\mathrm{CO}_{2}$ emissions limits: an economic cost analysis for the USA. Energy J., 11: 51-85.

Nelkin, D. and Pollack, M., 1980. The Atom Besieged: Extra-parliamentary Dissent in France and Germany. MIT Press, Cambridge, Mass.

OECD, 1988. Transports et environnement. OECD, Paris, 145 pp.

OECD, 1989. Instruments économiques et protection de l'environnement. OECD, Paris.

Pcarce, F., 1990. Whatever happened to acid rain? New Sci., 15: 57-60.

Pearce, D. and Markandya, A., 1990. Environmental policy benefits: monetary valuation. OECD, Paris, 91 pp.

Pearce, D.W., Barbier, E.B. and Markandya, A., 1989. Sustainable Development: Economics and Environment in the Third World. Edward Edgar, London.

Perrings, C., 1989. Environmental bonds and environmental research in innovative activities. Ecol. Econ., 1: 95-110.

Puiseux, L., 1982. Les bifurcations de la politique énergétique française. Annales, 4: $609-620$.

Roqueplo, Ph., 1988a. Pluies acides: menaces pour l'Europe. Economica CPE, Paris, 362 pp.

Roqueplo, Ph., 1988b. Expertise scientifique: le cas des pluies acides. Recherche, 205.

Ruff, L.E., 1970. The Economic Common Sense of Pollution. The Public Interest, No. 19.

Salles, J.M., 1989. Décision en avenir controversé: la micro-économie comme enjeu et langage de négociations. Réflexions à partir de la crise des pluies acides en Europe. In: J. Theys (Editor), Environnement, Science et Politique. Experts are Categorical (Proceedings of a Symposium, 11-13 September, Arc-et-Senans, France). Cahiers du Germes 13, Paris, pp. 281-321.

Salles, J.M., 1990. De la mort des forêts à la voiture propre. Les enjeux économiques de la controverse des pluies acides en Europe. CIRED, Rapport pour le Groupe de Prospective du Ministère de l'environnement (unpubl.), $103 \mathrm{pp}$

Simon, H.A., 1976. From substantive to procedural rationality. In: S. Latsis (Editor), Method and Appraisal in Economics. Cambridge University Press, Cambridge, pp. $129-148$.

Scimeni, G., 1987. Environmental politics and anticipatory strategies. IIUG, Berlin, published in: U.E. Simonis 1988 (Editor), Präventive Umweltpolitik. Campus, Frankfurt/New York.

Valroff, J., 1985. Pollution atmosphérique et pluies acides. Rapport au Premier Ministre, Paris, La Documentation française, september, $275 \mathrm{pp}$. 